\title{
Peningkatan Kemampuan Berpikir Kritis Melalui Model Think Pair Share Berbantuan Permainan Engklek pada Siswa Sekolah Dasar
}

\author{
Alvina Damayanti ${ }^{1]}$, Ika Ari Pratiwi ${ }^{2]}$, Erik Aditia Ismaya ${ }^{3]}$ \\ Universitas Muria Kudus \\ E-mail: ${ }^{1]}$ kudusdus36@gmail.com \\ ${ }^{2]}$ Ika.Ari@umk.ac.id \\ ${ }^{3]}$ erik.aditia@umk.ac.id
}

\begin{abstract}
Abstrak
Dilakukannya penelitian ini meliputi latar belakang berdasarkan rendahnya kemampuan berpikir kritis siswa. Tujuan penelitian ini yaitu untuk mendeskripsikan peningkatan kemampuan berpikir kritis siswa melalui model Think Pair Share berbantuan permainan tradisional Engklek pada tema 6 kelas V SD 2 Getas Pejaten. Metode penelitian yang digunakan yakni penelitian tindakan kelas yang dilaksanakan dua siklus, setiap siklus terdapat empat tahap yakni perencanaan, pelaksanaan, observasi dan refleksi. Lokasi penelitian di SD 2 Getas Pejaten yang beralamat di Jl. Sentot Prawirodirjo, Getas Pejaten, Kabupaten Kudus. Subjek penelitian yaitu siswa kelas V SD 2 Getas Pejaten semester I tahun ajaran 2019/2020 yang berjumlah 20 siswa, terdiri dari 9 perempuan dan 11 laki-laki. Sumber data penelitian yaitu siswa kelas V SD 2 Getas Pejaten. Teknik pengumpulan data meliputi teknik wawancara, observasi, tes, dan dokumentasi. Validitas data yang digunakan yaitu Expert Judgement dengan menggunakan teknik analisis data kualitatif dan kuantitatif. Hasil penelitian menunjukkan adanya peningkatan pada kemampuan berpikir kritis siswa. Hasil kemampuan berpikir kritis siswa siklus I muatan IPS memperoleh rata-rata 76 dengan ketuntasan klasikal 55\%. Muatan PPKn dengan rata-rata 78 dengan ketuntasan klasikal $75 \%$. Siklus II muatan IPS memperoleh rata-rata 86 dengan ketuntasan klasikal $75 \%$ dan muatan PPKn dengan rata-rata 88 dengan ketuntasan klasikal $85 \%$. Berdasarkan hasil penelitian dapat disimpulkan bahwa penggunaan model Think Pair Share berbantuan permainan tradisional Engklek dapat meningkatkan kemampuan berpikir kritis siswa.
\end{abstract}

Kata Kunci: Permainan Engklek, Think Pair Share, Tema 6

\section{Increased Critical Thinking Ability Through Think Pair Share Models Assisted by Engklek Games in Elementary School Students}

\begin{abstract}
The conduct of this study includes a background based on low critical thinking skills of students. The purpose of this study was to describe the improvement of students' critical thinking skills through the Think Pair Share model assisted by traditional Engklek games on the theme grade 6 V SD 2 Getas Pejaten. The research method used is classroom action research conducted two cycles, each cycle there are four stages namely planning, implementing, observing and reflecting. Research location at SD 2
\end{abstract}


Getas Pejaten which is located at Jl. Sentot Prawirodirjo, Getas Pejaten, Kudus Regency. The subject of the research is the fifth grade students of SD 2 Getas Pejaten semester I of the 2019/2020 school year, totaling 20 students, consisting of 9 women and 11 men. Research data sources are students in class V SD 2 Getas Pejaten. Data collection techniques include interview, observation, test, and documentation techniques. The validity of the data used is Expert Judgment using qualitative and quantitative data analysis techniques. The results showed an increase in students' critical thinking skills. The results of the critical thinking skills of students in the first cycle of social studies content gained an average of 76 with a classical completeness of 55\%. Civic content with an average of 78 with $75 \%$ classical completeness. Cycle II IPS content obtained an average of 86 with $75 \%$ classical completeness and civic content with an average of 88 with $85 \%$ classical completeness. Based on the results of the study it can be concluded that the use of Think Pair Share models assisted by the traditional Engklek game can improve students' critical thinking skills.

Keywords: Engklek Game, Think Pair Share, Theme 6

\section{PENDAHULUAN}

Pada dasarnya pendidikan merupakan kebutuhan yang harus terpenuhi setiap peserta didik untuk mewujudkan terciptanya proses pembelajaran yang dapat mengembangkan potensi seseorang. Pendidikan adalah usaha sadar dan terencana untuk mewujudkan suasana belajar dan proses pembelajaran agar peserta didik secara aktif mengembangkan potensi dirinya untuk memiliki kekuatan spiritual, keagamaan, pengendalian diri, kepribadian, kecerdasan, akhlak mulia, serta keterampilan yang diperlukan dirinya, masyarakat, bangsa dan negara.

Tujuan pendidikan dasar adalah untuk berkembangnya potensi peserta didik agar menjadi manusia yang beriman dan bertakwa kepada Tuhan Yang Maha Esa, berakhlak mulia, sehat, berilmu, cakap, kreatif, mandiri, dan menjadi warga negara yang demokratis serta bertanggung jawab. Hal ini berarti proses pendidikan berujung pada pembentukan sikap, kecerdasan dan keterampilan siswa. Ketiga aspek ini merupakan arah dan tujuan pendidikan yang harus diupayakan.
Pendidikan sangat berkaitan erat dengan dengan dunia sekolah. Kegiatan pembelajaran di sekolah membutuhkan suatu pedoman penyelenggaraan pembelajaran berupa kurikulum. Peraturan pemerintah tentang standar nasional pendidikan menjelaskan bahwa kurikulum adalah seperangkat rencana dan pengaturan mengenai tujuan, isi, dan bahan pelajaran serta cara yang digunakan sebagai pedoman penyelenggaraan kegiatan pembelajaran untuk mencapai tujuan pendidikan.

Kurikulum Indonesia senantiasa mengalami perubahan mengikuti perkembangan zaman. Mulai dari kurikulum 1947 sampai dengan kurikulum yang sekarang yaitu kurikulum 2013. Saat ini Indonesia menerapkan kurikulum 2013, yang merupakan penyempurnaan, modivikasi dari kurikulum sebelumnya. Pemerintah mulai menerapkan kurikulum 2013 di setiap jenjang pendidikan sekolah, khususnya tingkat SD/MI. Salah satu ciri kurikulum 2013 adalah bersifat tematik integratif.

Pembelajaran tematik merupakan salah satu model pembelajaran terpadu yang menggunakan tema untuk 
mengaitkan beberapa mata pelajaran sehingga dapat memberikan pengalaman bermakna bagi peserta didik. Disimpulkan bahwa dalam kurikulum 2013 pembelajaran tematik terpadu merupakan pembelajaran yang menggunakan tema untuk mengaitkan mata pelajaran secara terpadu sehingga dapat memberikan pengalaman yang bermakna pada peserta didik. Implementasi Kurikulum 2013 di SD 2 Getas Pejaten sudah diterapkan pembelajaran dengan pendekatan tematik terpadu dari Kelas satu sampai kelas enam di antaranya pada Mata pelajaran IPS dan PPKn.

$$
\text { Susanto (2013: }
$$

menjelaskan pendidikan IPS adalah penyederhanaan atau adaptasi dari disiplin ilmu-ilmu sosial dan humaniora, serta kegiatan dasar manusia yang diorganisasikan dan disajikan secara ilmiah dan pedagogis/psikologis untuk tujuan pendidikan. Tujuan pembelajaran IPS adalah agar masyarakat mengetahui tentang karakteristik geografis Indonesia sebagai negara kepulauan atau maritim dan agraris serta pengaruhnya terhadap kehidupan ekonomi, sosial, budaya, komunikasi serta transportasi.

Susanto (2013: 225) menjelaskan bahwa PPKn adalah mata pelajaran yang digunakan sebagai wahana untuk mengembangkan dan melestarikan nilai luhur dan moral yang berakar pada budaya bangsa Indonesia. Tujuan pembelajaran PPKn adalah agar warga negara Indonesia dapat menggali manfaat persatuan dan keatuan untuk membangun kerukunan hidup. Salah satu cara untuk membentuk siswa menjadi warga negara yang bisa memanfaatkan persatuan dan keatuan untuk membangun kerukunan hidup adalah dengan memberikan pembelajaran PPKn dengan benar.
Berdasarkan observasi yang dilakukan peneliti di kelas V SD 2 Getas Pejaten ditemukan beberapa masalah pada proses pembelajaran yaitu guru masih kebingungan dalam menerpakan model pembelajaran yang inovatif dan guru masih bingung dalam menerapkan media pembelajaran sesuai dengan karakteristik anak. Sebagian besar siswa yang kurang menanggapi pertanyaan yang diajukan oleh guru. Siswa hanya menunggu jawaban dari teman dan juga guru tanpa mencoba untuk memikirkan jawabnya sendiri. Kebiasaan seperti inilah yang mengakibatkan kemampuan berpikir kritis siswa tidak maksimal.

Berdasarkan hasil wawancara guru dan siswa Kelas V SD 2 Getas Pejaten, diketahui bahwa sebagian besar kemampuan berpikir kritis siswa masih rendah. Sebagian siswa ada yang berani mengungkapkan pendapatnya dan sebagian besar siswa masih pasif dan tidak berani berpendapat, siswa masih kesulitan dalam memecahkan persoalan yang mereka hadapi.

Berdasarkan hasil nilai prasiklus yang dilakukan di SD 2 Getas Pejaten dari 20 siswa, 8 siswa memiliki kemampuan berpikir kritis sedang hingga tinggi dengan persentase ketuntasan klasikal 40\%. Sedangkan 12 siswa masih memiliki kemampuan berpikir kritis yang masih rendah dengan persentase ketuntasan klasikal 60\%. Saat observasi prasiklus juga di temukan bahawa peserta didik masih menyamakan jawabannya dengan yang ada di dalam buku, peserta didik masih belum mampu menjawab pertanyaanpertanyaan di dalam buku hanya dengan membaca, memahami, menganalisis dan menjawab setiap pertanyaan dengan bahasanya sendiri.

Berdasarkan adanya permasalahan tersebut perlu adanya upaya untuk meningkatkan kemampuan berpikir kritis siswa agar memiliki kemampuan 
berpikir kritis yang lebih baik. Berdasarkan diskusi dan kesepakatan dari guru untuk meningkatkan kemampuan berpikir kritis siswa dalam pembelajaran tematik IPS dan PPKn di kelas V SD 2 Getas Pejaten adalah dengan menggunakan model Think Phair Share berbantuan permainan tradisional Engklek.

Model Think Pair Share (TPS) adalah suatu model pembelajaran kooperatif yang memberi siswa waktu untuk berpikir dan merespon serta saling bantu satu sama lain. Shoimin (2014: 208) menjelaskan Think Pair Share (TPS) adalah suatu model pembelajaran kooperatif yang memberi siswa waktu untuk berpikir dan merespon serta saling bantu satu sama lain. Prasetyo et al (2018: 5) menjelaskan Think Pair Share (TPS) adalah model pembelajaran yang membagikan pemikiran secara bepasang-pasangan atau berfikir secara berpasang-pasangan.

$$
\text { Daryanto (2014: }
$$

menjelaskan bahwa Think Pair Share merupakan model pembelajaran sederhana dengan banyak keuntungan karena dapat meningkatkan partisipasi siswa dan pembentukan pengetahuan oleh siswa.

Think Pair Share ini telah direkomendasikan untuk pembelajaran karena dapat mengekspresikan penalaran siswa, merefleksikan pikiran siswa dan memperoleh umpan balik berupa pemahaman langsung dari mereka.

Model Think Pair Share memiliki banyak kelebihan dan manfaat, di antaranya untuk menciptakan pembelajaran yang menarik sehingga siswa dapat dengan mudah memahami materi yang disampaikan, dapat memacu keberanian siswa dalam menyampaikan pendapat, memfasilitasi siswa dengan pengalaman kepemimpinan, membuat keputusan dalam kelompok, memberikan kesempatan kepada siswa untuk berinteraksi dan belajar bersamasama memberi siswa waktu untuk berpikir, menjawab, saling membantu satu sama lain. Demikian siswa diharapkan mampu bekerja sama, saling membantu, serta kemampuan berpikir kritis siswa menjadi lebih meningkat dan lebih baik.

Metode bermain atau permainan juga dapat membuat susana pembelajaran menjadi lebih nyaman dan menyenangkan dan tidak akan menimbulkan kejenuhan pada siswa, sehingga mereka dapat memusatkan perhatian penuh terhadap materi pelajaran. Media permainan memiliki jenis yang sangat banyak, salah satunya media permainan yang dapat membantu guru dalam pembelajaran adalah media permainan Engklek.

Fad (2014: 68) menjelaskan bahwa permainan Engklek adalah permainan yang dimulai dengan menentukan pemain yang bermain pertama dengan melempar pecahan genting mulai dari kotak 1 menggunakan satu kaki. Wardani (2010:15) menjelaskan bahwa permaianan Engklek disebut juga Somdah. Somdah merupakan permainan yang menggunakan media gambar persegi empat yang digambar di lantai ataupun di tanah. Wulandari (2012:131) menjelaskan bahwa permainan Engklek adalah permainan lompat-lompat kotak dengan satu kaki dan berhenti dengan dua kaki pada kotak-kotak tertentu. tertentu.

Engklek merupakan permainan tradisional diharapkan dapat digunakan sebagai sarana pembelajaran. Engklek mengandung nilai-nilai budi pekerti yang bermanfaat bagi siswa. Siswa tidak hanya belajar saja namun sesekali mereka dibiarkan belajar sambil 
bermain sehingga membuat pembelajaran lebih menarik, seru, dan tidak monoton, komunikasi antara siswa dan guru menjadi lebih lancar dan santai sehingga pesan yang ingin disampaikan guru dapat tercapai.

Pemilihan model pembelajaran Think Pair Share (TPS) sebagai upaya perbaikan serta peningkatan kualitas pembelajaran pada siswa kelas V SD 2 Getas Pejaten senada dengan riset Nasution et al (2017), Kusumaningsih (2019), Hasibuan et al (2018), Syaifullah (2017), Hatma (2017). dan Hidayah et al (2019). Adapun perbedaan penelitian yang dilakukan dengan riset tersebut diatas yaitu pada pemilihan media, subyek penelitian, matapelajaran, serta lokasi penelitian..

Berdasarkan latar belakang diatas maka dilakukan penelitian dengan tujuan menganalisa kemampuan berpikir kritis siswa kelas V SD 2 Getas Pejaten dengan diterapkannya model pembelajaran Think Pair Share berbantuan permainan tradisional Engklek pada Tema 6 Panas dan Perpindahanya muatan IPS dan PPKn siswa kelas V SD 2 Getas Pejaten pada tahun 2019/2020.

\section{METODE}

Metode penelitian yang digunakan yakni penelitian tindakan kelas (PTK) yang dilaksanakan dalam dua siklus, setiap siklus terdiri dari empat tahap yakni perencanaan, pelaksanaan, observasi dan refleksi. Lokasi penelitian di SD 2 Getas Pejaten yang beralamat di Jl. Sentot Prawirodirjo No. 984 A, Getas Pejaten, Kabupaten Kudus. Subjek penelitian yaitu siswa kelas V SD 2 Getas Pejaten semester I tahun ajaran 2019/2020 yang berjumlah 20 siswa yang terdiri dari 9 perempuan dan 11 laki-laki. Sumber data penelitian yaitu siswa. Teknik pengumpulan data meliputi teknik wawancara, observasi, tes, dan dokumentasi. Validitas data yang digunakan yaitu Expert Judgement dengan menggunakan teknik analisis data kualitatif dan kuantitatif.

\section{HASIL DAN PEMBAHASAN}

Penelitian tindakan kelas dilakukan dengan persetujuan guru kelas V SD 2 Getas Pejaten dengan waktu pelaksanaan siklus I pada tanggal 7 dan 8 Januari 2020 dan siklus II dilaksanakan pada tanggal 14 dan 16 Januari 2020.

\section{Siklus I}

\section{a. Perencanaan}

Perencanaan ini dimaksudkan agar dalam pelaksanaan pembelajaran dapat berjalan dengan baik dan dapat mencapai tujuan pembelajaran yang diharapkan. Kegiatan perencanaan dalam penelitian siklus I berupa penyusunan silabus dan Rencana Pelaksanaan Pembelajaran (RPP), mempersiapkan media pembelajaran. Penelitian ini media yang digunakan yaitu media permainan tradisional Engklek dan Papan Informasi (Papin). Peneliti menyiapkan Lembar Kegiatan Siswa (LKS), dan evaluasi pembelajaran yang berbentuk tes uraian.

\section{b. Pelaksanaan}

Tahap kedua dari penelitian tindakan ini yakni pelaksanaan. Penelitian dilaksanakan dengan menerapkan model pembelajaran Think Pair Share berbantuan permainan tradisional Engklek untuk meningkatkan kemmapuan bepikir kritis siswa kelas $\mathrm{V}$ SD 2 Getas Pejaten pada tema 6 panas dan perpindahanya.

Penelitian siklus I pertemuan 1 dilaksanakan hari Selasa, 7 Januari 2020 pukul 10.00 - 12.20 WIB dengan alokasi waktu $4 \times 35$ menit. Adapun 
materi yang diajarkan yaitu Interaksi sosial budaya dan ekonomi untuk muatan IPS dan Kewajiban, hak, dan tanggung jawab sebagai siswa untuk muatan PPKn. Pada tahap pelaksanaan, terdapat tiga kegiatan yaitu kegiatan pendahuluan, kegiatan inti, dan kegiatan penutup.

Kegiatan pendahuluan berupa kegiatan guru untuk mengondisikan kelas, membuka pembelajaran dengan salam dan berdoa, menyanyikan lagu "Garuda Pancasila", mengecek kehadiran siswa, serta menyampaikan tujuan pembelajaran. Kegiatan selanjutnya yakni pelaksanaan langkahlangkah model pembelajaran Think Pair Share (TPS). Adapun langkah-langkah Think Pair Share (TPS) meliputi 1) Think (Berpikir), 2) Pair (berpasangan), 3) Share (Berbagi).

Kegiatan penutup diawali guru dengan tindakan refleksi dan memberikan penguatan (reinforcement). Ketika kegiatan penguatan siswa pun terlihat mendengarkan dengan seksama dan setelah itu siswa berdoa untuk mengakhiri pembelajaran. Kegiatan penutup berjalan dengan lancar tanpa ditemukan adanya siswa melanggar peraturan.

Penelitian siklus I pertemuan 2 dilaksanakan hari Rabu, 8 Januari 2020 pukul 09.10-12.10WIB dengan alokasi waktu $4 \times 35$ menit. Siklus I pertemuan 2 merupakan kelanjutan dari siklus I pertemuan 1. Pada siklus I pertemuan 2 materi yang disampaikan yakni mengenai bentuk-bentuk interaksi manusia dengan lingkungan dan pengaruhnya terhadap pembangunan sosial budaya dan ekonomi untuk muatan IPS dan kewajiban, hak, dan tanggung jawab sebagai sebagai warga masyarakat dan siswa untuk muatan PPKn. Pembelajaran pada siklus 1 pertemuan 2 mengacu pada Rencana Pelaksanaan Pembelajaran (RPP) yang telah dibuat yakni kegiatan pendahuluan, kegiatan inti, dan kegiatan penutup.

Pembelajaran pada siklus I pertemuan 2 diawali dengan kegiatan pendahuluan. Guru membuka pembelajaran dengan mengcap salam dan berdoa, menyanyikan lagu "Tanah Airku", dan mengecek kehadiran siswa. Kegiatan selanjutnya yakni pelaksanaan langkah-langkah model pembelajaran Think Pair Share (TPS). Adapun langkah-langkah Think Pair Share (TPS) meliputi 1) Think (Berpikir), 2) Pair (berpasangan), 3) Share (Berbagi).

Pada kegiatan penutup siswa terlebih dahulu mengerjakan soal tes evaluasi yang diberikan guru. Siswa mengerjakan soal tes evaluasi dengan tenang. Setelah mengerjakan soal tes kemudian siswa bersama guru melakukan refleksi dan guru pun memberikan penguatan. Setelah itu siswa kemudian berdoa untuk mengakhiri pembelajaran dan siswa terlihat dapat mengikuti kegiatan penutup dengan tenang dan tertib.

\section{c. Observasi}

Pada tahap observasi, dilakukan pengamatan terhadap kemampuan berpikir kritis siswa. Data dikumpulkan peneliti dengan menggunakan lembar observasi kemampuan berpikir kritis siswa.

Kemampuan berpikir kritis siswa pada siklus I diketahui dari hasil soal tes evaluasi yang berjumlah sepuluh soal (lima soal muatan IPS dan lima soal muatan PPKn). Tes evaluasi siklus I dilaksanakan pada Rabu, 8 Januari 2020. Berdasarkan hasil tes evaluasi diketahui bahwa kemampuan berpikir kritis siswa pada siklus I muatan IPS memperoleh nilai rata-rata 76 dengan nilai tertinggi 95 dan nilai terendah 55 . Pada siklus I muatan IPS diketahui siswa yang tuntas sebanyak 11 orang 
dan siswa yang tidak tuntas sebanyak 9 orang. Dengan demikian dapat diketahui bahwa persentase ketuntasan klasikal kemampuan berpikir kritis siswa siklus I muatan IPS yakni 55\% dengan kriteria kurang. Untuk lebih jelasnya hasil kemampuan berpikir kritis siswa muatan IPS siklus I dapat dilihat pada Tabel 1 di bawah ini.

Tabel 1. Hasil Kemampuan Berpikir Kristis Siswa pada siklus I Muatan IPS

\begin{tabular}{cccc}
\hline No. & $\begin{array}{c}\text { Nama } \\
\text { Siswa }\end{array}$ & $\begin{array}{c}\text { Siklus I } \\
\text { IPS }\end{array}$ & Keterangan \\
\hline $\mathbf{1}$ & AAR & 65 & Tidak Kritis \\
$\mathbf{2}$ & AS & 70 & Tidak Kritis \\
$\mathbf{3}$ & BDW & 75 & Kritis \\
$\mathbf{4}$ & DIF & 60 & Tidak Kritis \\
$\mathbf{5}$ & IH & 65 & Tidak Kritis \\
$\mathbf{6}$ & IW & 60 & Tidak Kritis \\
$\mathbf{7}$ & JW & 95 & Kritis \\
$\mathbf{8}$ & KNO & 90 & Kritis \\
$\mathbf{9}$ & MPA & 60 & Tidak Kritis \\
$\mathbf{1 0}$ & MCH & 85 & Kritis \\
$\mathbf{1 1}$ & MKA & 85 & Kritis \\
$\mathbf{1 2}$ & NMF & 95 & Kritis \\
$\mathbf{1 3}$ & NA & 85 & Kritis \\
$\mathbf{1 4}$ & NEM & 55 & Tidak Kritis \\
$\mathbf{1 5}$ & TPL & 80 & Kritis \\
$\mathbf{1 6}$ & ZAA & 80 & Kritis \\
$\mathbf{1 7}$ & RHK & 70 & Tidak Kritis \\
$\mathbf{1 8}$ & AFS & 55 & Tidak Kritis \\
$\mathbf{1 9}$ & KP & 90 & Kritis \\
$\mathbf{2 0}$ & PIH & 95 & Kritis \\
Jumlah & 1,515 & \\
Rata-rata & 76 & \\
Kriteria & Cukup & \\
Jumlah Siwa & 9 & \\
Tidak Tuntas & & \\
Persentase & $45 \%$ & \\
Jumlah Siswa & 11 & \\
Tuntas & & \\
Persentase & $55 \%$ & \\
\hline & & & \\
&
\end{tabular}

Tabel 1 diatas dapat disimpulkan bahwa kemampuan berpikir kritis siswa pada siklus I muatan IPS memperoleh nilai rata-rata 76 dengan nilai tertinggi 95 dan nilai terendah 55. Pada siklus I muatan IPS siswa yang tuntas sebanyak 11 orang dan siswa yang tidak tuntas sebanyak 9 orang. Kemampuan berpikir kritis siswa pada siklus I muatan IPS memperoleh nilai rata-rata 76 dengan nilai tertinggi 95 dan nilai terendah 55 . Pada siklus I muatan IPS diketahui siswa yang tuntas sebanyak 11 orang dan siswa yang tidak tuntas sebanyak 9 orang.

Kemampuan berpikir kritis siswa siklus I muatan PPKn diketahui bahwa memperoleh nilai rata-rata 78 dengan nilai tertinggi 95 dan nilai terendah 55 . Pada siklus I muatan PPKn diketahui siswa yang tuntas sebanyak 12 orang dan siswa yang tidak tuntas sebanyak 8 orang. Dengan demikian dapat diketahui bahwa persentase ketuntasan klasikal kemampuan berpikir kritis siswa siklus I muatan PPKn yakni $60 \%$ dengan kriteria kurang. Untuk lebih jelasnya hasil kemampuan berpikir kritis siswa muatan PPKn siklus I dapat dilihat pada Tabel 2 di bawah ini.

Tabel 2. Hasil Kemampuan Berpikir Kristis Siswa pada siklus I Muatan PPKn.

\begin{tabular}{cccc}
\hline No. & $\begin{array}{c}\text { Nama } \\
\text { Siswa }\end{array}$ & $\begin{array}{c}\text { Siklus } \\
\text { I } \\
\text { PPKn }\end{array}$ & Keterangan \\
\hline $\mathbf{1}$ & AAR & 70 & Tidak Kritis \\
$\mathbf{2}$ & AS & 60 & Tidak Kritis \\
$\mathbf{3}$ & BDW & 85 & Kritis \\
$\mathbf{4}$ & DIF & 85 & Kritis \\
$\mathbf{5}$ & IH & 55 & Tidak Kritis \\
$\mathbf{6}$ & IW & 60 & Tidak Kritis \\
$\mathbf{7}$ & JW & 70 & Tidak Kritis \\
$\mathbf{8}$ & KNO & 95 & Kritis \\
$\mathbf{9}$ & MPA & 70 & Tidak Kritis \\
$\mathbf{1 0}$ & MCH & 95 & Kritis \\
$\mathbf{1 1}$ & MKA & 95 & Kritis \\
$\mathbf{1 2}$ & NMF & 90 & Kritis \\
$\mathbf{1 3}$ & NA & 65 & Tidak Kritis
\end{tabular}




\begin{tabular}{cccc}
$\mathbf{1 4}$ & NEM & 70 & Tidak Kritis \\
$\mathbf{1 5}$ & TPL & 75 & Kritis \\
$\mathbf{1 6}$ & ZAA & 85 & Kritis \\
$\mathbf{1 7}$ & RHK & 75 & Kritis \\
$\mathbf{1 8}$ & AFS & 95 & Kritis \\
$\mathbf{1 9}$ & KP & 80 & Kritis \\
$\mathbf{2 0}$ & PIH & 90 & Kritis \\
Jumlah & 1,565 & \\
Rata-rata & 78 & \\
Kriteria & Cukup \\
Jumlah Siwa & 8 & \\
Tidak Tuntas & & \\
Persentase & $40 \%$ & \\
Jumlah Siswa & 12 & \\
Tuntas & & \\
Persentase & $60 \%$ & \\
\hline
\end{tabular}

Tabel 2 di atas memperlihatkan bahwa setelah melaksanakan tes evaluasi siklus I, diperoleh nilai ratarata untuk muatan PPKn rata-ratanya yaitu 78 nilai tertinggi 95 sedangkan nilai terendah 55 terdapat 12 peserta didik yang berpikir kritis dengan persentase sebanyak $60 \%$ dan 8 peserta didik yang kurang kritis dengan persentase $40 \%$.

Berdasarkan data penelitian maka kemampuan berpikir kritis siswa siklus I muatan IPS belum mencapai indikator keberhasilan, sedangkan untuk muatan PPKn belum mencapai indikator keberhasilan. Indikator keberhasilan dalam penelitian ini yakni ketuntasan klasikal sebesar $75 \%$.

Untuk lebih jelasnya persentase kemampuan berpikir kristis siswa siklus I dapat dilihat pada gambar dibawah ini.

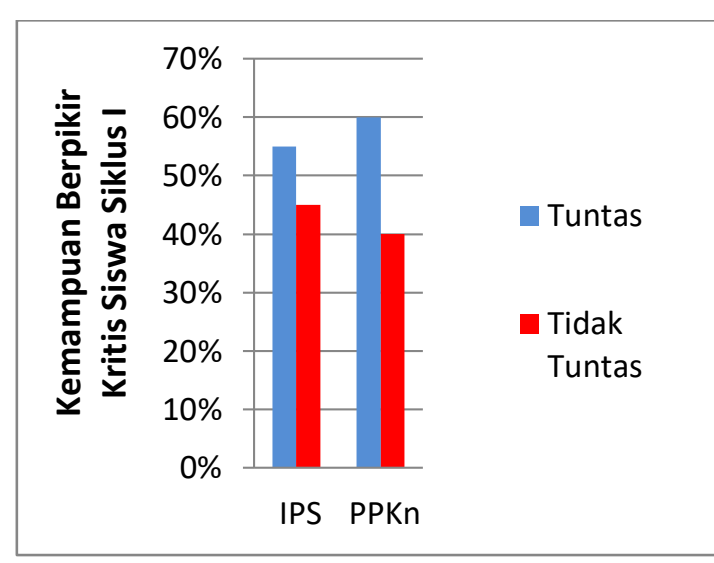

\section{Gambar 1. Kemampuan Berpikir Kritis Siswa Siklus I}

\section{d. Refleksi}

Tahap ini peneliti bersama observer melakukan refleksi untuk mengetahui hasil siklus I yang kemudian dicari solusinya dengan tujuan dapat diperbaiki pada siklus II. Berikut hasil refleksi siklus I antara lain 1) kemampuan berpikir kritis siswa muatan IPS dan PPKn pada siklus I belum menacapai indikator keberhasilan sehingga harus diperbaiki supaya meningkat, 2) masih ada siswa yang tidak mendengarkan ketika dijelaskan, siswa sering kali keluar dari tempat duduknya, tidak mau berkelompok dan siswa yang asik bermain atau mengobrol dengan temannya saat pembelajaran.

Berdasarkan pada refleksi siklus I maka peneliti melanjutkan penelitian ke siklus II. Pada siklus II peneliti berharap dapat memperbaiki kesalahan dan dapat meningkatkan kemampuan berpikir kritis siswa.

\section{Siklus II}

\section{a. Perencanaan}

Perencanaan ini dimaksudkan agar dalam pelaksanaan pembelajaran dapat berjalan dengan baik dan dapat mencapai tujuan pembelajaran yang diharapkan. Kegiatan perencanaan dalam penelitian siklus I berupa 
penyusunan silabus dan Rencana Pelaksanaan Pembelajaran (RPP), mempersiapkan media pembelajaran. Penelitian ini media yang digunakan yaitu media permainan tradisional Engklek dan Papan Informasi (Papin). peneliti menyiapkan Lembar Kegiatan Siswa (LKS), evaluasi pembelajaran yang berbentuk tes uraian dan menyiapkan instrumen penelitian berupa lembar pengamatan siswa dan guru.

\section{b. Pelaksanaan}

Tahap kedua dari penelitian tindakan ini yakni pelaksanaan. Penelitian dilaksanakan dengan menerapkan model pembelajaran Think Pair Share (TPS) berbantuan permainan tradisional Engklek untuk meningkatkan kemmapuan bepikir kritis siswa kelas V SD 2 Getas Pejaten pada tema 6 panas dan perpindahanya.

Penelitian siklus II pertemuan 1 dilaksanakan hari Selasa, 14 Januari 2020 pukul 10.00 - 12.20 WIB dengan alokasi waktu $4 \times 35$ menit. Adapun materi yang diajarkan yaitu Interaksi manusia dengan lingkungan dan pengaruhnya terhadap pembangunan sosial, budaya, dan ekonomi untuk muatan IPS dan kewajiban, hak, dan tanggung jawab sebagai sebagai warga masyarakat untuk muatan PPKn. Pada tahap pelaksanaan, terdapat tiga kegiatan yaitu kegiatan pendahuluan, kegiatan inti, dan kegiatan penutup.

Kegiatan pendahuluan berupa kegiatan guru untuk mengondisikan kelas, membuka pembelajaran dengan salam dan berdoa, menyanyikan lagu "Tanah Air", mengecek kehadiran siswa, serta menyampaikan tujuan pembelajaran. Kegiatan selanjutnya yakni pelaksanaan langkah-langkah model pembelajaran Think Pair Share (TPS). Adapun langkah-langkah Think Pair Share (TPS) meliputi 1) Think
(Berpikir), 2) Pair (berpasangan), 3) Share (Berbagi).

Kegiatan penutup diawali guru dengan tindakan refleksi dan memberikan penguatan (reinforcement). Ketika kegiatan penguatan siswa pun terlihat mendengarkan dengan seksama dan setelah itu siswa menyanyikan lagu daerah kemudian berdoa untuk mengakhiri pembelajaran. Kegiatan penutup berjalan dengan lancar tanpa ditemukan adanya siswa melanggar peraturan.

Penelitian siklus II pertemuan 2 dilaksanakan hari Kamis, 16 Januari 2020 pukul 09.10-12.10 WIB dengan alokasi waktu $4 \times 35$ menit. Siklus II pertemuan 2 merupakan kelanjutan dari siklus II pertemuan 1. Pada siklus II pertemuan 2 materi yang disampaikan yakni bentuk interaksi manusia dengan lingkungan dan pengaruhnya terhadap pembangunan ekonomi dan sosial budaya dalam masyarakat untuk muatan IPS sedangkan materi muatan PPKn adalah hak, kewajiban dan tanggung jawab masyarakat. Pembelajaran pada siklus I1 pertemuan 2 mengacu pada Rencana Pelaksanaan Pembelajaran (RPP) yang telah dibuat yakni kegiatan pendahuluan, kegiatan inti, dan kegiatan penutup.

Pembelajaran pada siklus II pertemuan 2 diawali dengan kegiatan pendahuluan. Guru membuka pembelajaran dengan salam dan berdoa, menyanyikan lagu "Maju Tak Gentar", dan mengecek kehadiran siswa. Kegiatan selanjutnya yakni pelaksanaan langkah-langkah model pembelajaran Think Pair Share (TPS). Adapun langkah-langkah Think Pair Share (TPS) meliputi 1) Think (Berpikir), 2) Pair (berpasangan), 3) Share (Berbagi).

Pada kegiatan penutup siswa terlebih dahulu mengerjakan soal tes 
evaluasi yang diberikan guru. Siswa mengerjakan soal tes evaluasi dengan tenang. Setelah mengerjakan soal tes kemudian siswa bersama guru melakukan refleksi dan guru pun memberikan penguatan. Setelah itu siswa menyanyikan lagu daerah kemudian berdoa untuk mengakhiri pembelajaran dan siswa terlihat dapat mengikuti kegiatan penutup dengan tenang dan tertib.

\section{c. Observasi}

Pada tahap observasi, dilakukan pengamatan terhadap kemampuan berpikir kritis siswa. Data dikumpulkan peneliti dengan menggunakan lembar kemampuan berpikir kritis siswa.

Kemampuan berpikir kritis siswa pada siklus II diketahui dari hasil soal tes evaluasi yang berjumlah sepuluh soal (lima soal muatan IPS dan lima soal muatan PPKn). Tes evaluasi siklus II dilaksanakan pada Rabu, 16 Januari 2020. Berdasarkan hasil tes evaluasi diketahui bahwa kemampuan berpikir kritis siswa pada siklus II muatan IPS memperoleh nilai rata-rata 86 dengan nilai tertinggi 100 dan nilai terendah 70. Pada siklus II muatan IPS diketahui siswa yang tuntas sebanyak 15 orang dan siswa yang tidak tuntas sebanyak 5 orang. Dengan demikian dapat diketahui bahwa persentase ketuntasan klasikal kemampuan berpikir kritis siswa siklus II muatan IPS yakni $75 \%$ dengan kriteria cukup. Untuk lebih jelasnya hasil kemampuan berpikir kritis siswa muatan IPS siklus II dapat dilihat pada Tabel 3 di bawah ini.

\section{Tabel 3. Hasil Kemampuan Berpikir Kristis Siswa pada siklus II Muatan IPS.}

\begin{tabular}{cccc}
\hline No. & $\begin{array}{c}\text { Nama } \\
\text { Siswa }\end{array}$ & $\begin{array}{c}\text { Siklus } \\
\text { II } \\
\text { IPS }\end{array}$ & Keterangan \\
\hline $\mathbf{1}$ & AAR & 70 & Tidak Kritis
\end{tabular}

\begin{tabular}{cccc}
$\mathbf{2}$ & AS & 80 & Kritis \\
$\mathbf{3}$ & BDW & 95 & Kritis \\
$\mathbf{4}$ & DIF & 70 & Tidak Kritis \\
$\mathbf{5}$ & IH & 70 & Tidak Kritis \\
$\mathbf{6}$ & IW & 80 & Kritis \\
$\mathbf{7}$ & JW & 90 & Kritis \\
$\mathbf{8}$ & KNO & 100 & Kritis \\
$\mathbf{9}$ & MPA & 70 & Tidak Kritis \\
$\mathbf{1 0}$ & MCH & 90 & Kritis \\
$\mathbf{1 1}$ & MKA & 95 & Kritis \\
$\mathbf{1 2}$ & NMF & 95 & Kritis \\
$\mathbf{1 3}$ & NA & 95 & Kritis \\
$\mathbf{1 4}$ & NEM & 85 & Kritis \\
$\mathbf{1 5}$ & TPL & 95 & Kritis \\
$\mathbf{1 6}$ & ZAA & 100 & Kritis \\
$\mathbf{1 7}$ & RHK & 85 & Kritis \\
$\mathbf{1 8}$ & AFS & 70 & Tidak Kritis \\
$\mathbf{1 9}$ & KP & 90 & Kritis \\
$\mathbf{2 0}$ & PIH & 95 & Kritis \\
Jumlah & 1,720 & \\
Rata-rata & 86 & \\
Kriteria & Baik \\
Jumlah Siwa & 15 & \\
Tuntas & & \\
Persentase & $75 \%$ & \\
Jumlah Siswa & 5 & \\
Tidak Tuntas & & \\
Persentase & $25 \%$ & \\
\hline & Tabel &
\end{tabular}

Tabel diatas memperlihatkan bahwa setelah melaksanakan tes evaluasi siklus II, diperoleh nilai ratarata untuk muatan IPS yaitu 86 , nilai tertinggi 100 sedangkan nilai terendahnya 70 , terdapat 15 peserta didik yang berpikir kritis dengan persentase sebanyak $75 \%$ dan 5 peserta didik kurang kritis dengan persentase $25 \%$.

Kemampuan berpikir kritis siswa siklus II muatan PPKn diketahui bahwa memperoleh nilai rata-rata 88 dengan nilai tertinggi 100 dan nilai terendah 70. Pada siklus II muatan PPKn diketahui siswa yang tuntas sebanyak 17 orang dan siswa yang tidak tuntas sebanyak 3 orang. Dengan demikian dapat diketahui bahwa persentase 
ketuntasan klasikal kemampuan berpikir kritis siswa siklus II muatan PPKn yakni $85 \%$ dengan kriteria baik. Untuk lebih jelasnya hasil kemampuan berpikir kritis siswa muatan PPKn siklus II dapat dilihat pada Tabel 4 di bawah ini.

Tabel 4. Hasil Kemampuan Berpikir Kristis Siswa pada siklus II Muatan PPKn.

\begin{tabular}{|c|c|c|c|}
\hline No. & $\begin{array}{l}\text { Nama } \\
\text { Siswa }\end{array}$ & $\begin{array}{c}\text { Siklus } \\
\text { II } \\
\text { PPKn }\end{array}$ & Keterangan \\
\hline 1 & AAR & 85 & Kritis \\
\hline 2 & AS & 70 & Tidak Kritis \\
\hline 3 & BDW & 80 & Kritis \\
\hline 4 & DIF & 85 & Kritis \\
\hline 5 & $\mathrm{IH}$ & 70 & Tidak Kritis \\
\hline 6 & IW & 85 & Kritis \\
\hline 7 & JW & 90 & Kritis \\
\hline 8 & KNO & 100 & Kritis \\
\hline 9 & MPA & 85 & Kritis \\
\hline 10 & $\mathrm{MCH}$ & 95 & Kritis \\
\hline 11 & MKA & 100 & Kritis \\
\hline 12 & NMF & 90 & Kritis \\
\hline 13 & NA & 100 & Kritis \\
\hline 14 & NEM & 70 & Tidak Kritis \\
\hline 15 & TPL & 85 & Kritis \\
\hline 16 & ZAA & 95 & Kritis \\
\hline 17 & RHK & 80 & Kritis \\
\hline 18 & AFS & 95 & Kritis \\
\hline 19 & KP & 90 & Kritis \\
\hline 20 & PIH & 100 & Kritis \\
\hline \multicolumn{2}{|c|}{ Jumlah } & 1,750 & \\
\hline \multicolumn{2}{|c|}{ Rata-rata } & 88 & \\
\hline \multicolumn{2}{|c|}{ Kriteria } & Baik & \\
\hline \multicolumn{2}{|c|}{ Jumlah Siwa } & 17 & \\
\hline \multicolumn{2}{|c|}{ Persentase } & $85 \%$ & \\
\hline \multicolumn{2}{|c|}{ Jumlah Siswa } & 3 & \\
\hline \multicolumn{4}{|c|}{ Tidak Tuntas } \\
\hline \multicolumn{2}{|c|}{ Persentase } & $15 \%$ & \\
\hline & Tabel & $4 d$ & atas dape \\
\hline
\end{tabular}

sebanyak 4 orang. Dengan demikian dapat diketahui bahwa persentase ketuntasan klasikal kemampuan berpikir kritis siswa siklus II muatan PPKn yakni $85 \%$ dengan kriteria baik. Berdasarkan data penelitian maka kemampuan berpikir kritis siswa siklus II muatan IPS dan PPKn sudah mencapai indikator keberhasilan. Indikator keberhasilan dalam penelitian ini yakni ketuntasan klasikal sebesar $75 \%$. Untuk lebih jelasnya persentase hasil belajar siklus I dapat dilihat pada gambar dibawah ini.

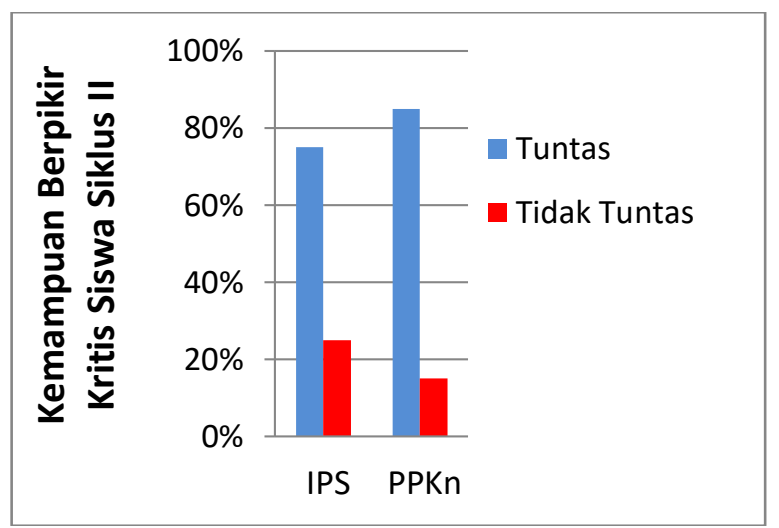

Gambar 2. Kemampuan Berpikir Kritis Siswa Siklus I

\section{d. Refleksi}

Tahap keempat dari penelitian tindakan kelas siklus II yaitu refleksi. Refleksi diadakan berdasarkan observasi dari kegiatan yang telah dilakukan observer pada penelitian siklus II. Berdasarkan data penelitian siklus II, diperoleh data kemampuan berpikir kritis siswa siklus II nilai ratarata muatan IPS yakni 86 dengan siswa yang tuntas sebanyak 15 orang dengan persentase ketuntasan $75 \%$ dan untuk muatan PPKn yakni 88 dengan siswa yang tuntas sebanyak 16 orang dengan persentase ketuntasan $80 \%$. Hasil tersebut dapat disimpulkan bahwa kemampuan berpikir kritis siswa untuk muatan IPS dan PPKn sudah mencapai indikator keberhasilan yaitu $\geq 75 \%$ dari jumlah siswa. 
Berdasarkan dari data yang telah diperoleh pada siklus II dapat disimpulkan bahwa penelitian yang dilakukan sudah mencapai hasil dari indikator keberhasilan yang sebelumnya telah ditetapkan. Oleh karena itu, penelitian dengan menerapkan model Think pair Share berbantuan permainan tradisional Engklek untuk meningkatkan kemampuan berpikir kritis siswa pada tema 6 kelas V SD 2 Getas Pejaten dilakukan sebanyak 2 siklus karena pada siklus kedua indikator keberhasilan sudah tercapai.

Hasil penelitian tindakan kelas yang telah dilakukan perlu dianalisa lebih lanjut sehingga menjadi jelas dan bermakna. Oleh karena itu pada bagian berikut disajikan analisa terhadap kemampuan berpikir kritis.

Kemampuan berpikir kritis siswa pada riset ini berlandasan pada pendapat Ennis dalam Susanto (2013: 125-126) yaitu: 1) memberikan penjelasan sederhana; 2) membangun keterampilan dasar; 3) menyimpulkan; 4) memberi penjelasan lanjut; 5) mengatur strategi dan taktik.

Hasil riset siklus I menunjukkan bahwa masih terdapat kekurangan dalam proses pembelajaran yakni dalam hal menyimpulkan. Ketika siswa minta untuk menyimpulkan sesuatu siswa masih menyamakan jawabannya dengan yang ada di dalam buku, siswa belum mampu menyimpulkan dengan bahasanya sendiri.

\section{Kekurangan-kekurangan}

tersebut diperbaiki pada siklus II. Dengan cara memaksimalkan pembelajaran dengan menerapkan model Think Pair Share berbantuan permainan tradisional Engklek. Kondisi yang terjadi setelah dilakukan perbaikan yakni persentase kemapuan berpikir kritis meningkat dan siswa menjadi aktif serta berani dan mampu menjawab pertanyaan-pertanyaan dengan bahasa mereka sendiri. kemampuan berpikir kritis siswa muatan IPS pada siklus II memperoleh persentase $75 \%$ dengan kualifikasi cukup, muatan PPKn memperoleh persentase $80 \%$ dengan kualifikasi baik.

Berdasarkan penjelasan tersebut dapat ditarik simpulan bahwa hipotesis tindakan yang diajukan telah terbukti dan indikator keberhasilan telah berhasil tercapai dengan memperoleh persentase sebesar $75 \%$ untuk IPS dan $80 \%$ untuk PPKn. Hasil tersebut sejalan dengan penelitian Hasibuan et al (2018) yang menerapkan model pembelajaran kooperatif tipe Think Pair Share (TPS). Hasil Penelitian ini terbukti dapat meningkatkan kemampuan berpikir kritis siswa, hal ini dapat dilihat dari siklus pertama belum mencapai indikator keberhasilan siswa dengan perolehan persentase $53,33 \%$ dan siswa yang tuntas berjumlah 16 orang. Setelah tindakan selanjutnya, di siklus kedua meningkat dengan persentase $83,33 \%$ dan sudah mencapai indikator keberhasilan siswa, untuk siswa yang tuntas berjumlah 25 orang dan sudah dikategorikan sangat baik.

\section{KESIMPULAN}

Berdasarkan hasil penelitian tindakan kelas dan pembahasan maka dapat disimpulkan bahwa penerapan model Think Pair Share berbantuan permainan tradisional engklek dapat meningkatkan kemampuan berpikir kritis siswa kelas V SD 2 Getas Pejaten pada tema 6 panas dan perpindahanya muatan IPS dan PPKn.

Hasil kemampuan berpikir kritis peserta didik tema 6 panas dan perpindahannya muatan IPS dan PPKn di kelas V SD 2 Getas Pejaten pada siklus I dengan persentase ketuntasan peserta didik pada muatan IPS yaitu 55\% dengan kualifikasi kurang, setelah 
itu melakukan perbaikan di siklus II mengalami peningkatan sebesar $25 \%$ dengan persentase ketuntasan menjadi 75\% kualifikasi cukup. Muatan PPKn persentase ketuntasan pada siklus I yaitu $75 \%$ dengan kualifikasi cukup, setelah melakukan perbaikan pada siklus II mengalami peningkatan sebesar $10 \%$ dengan persentas ketuntasan menjadi $85 \%$ dengan kualifikasi baik.

\section{DAFTAR PUSTAKA}

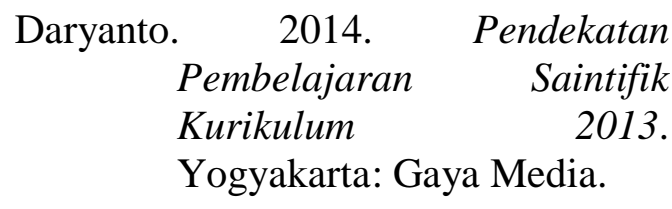

Dipraya dan Suwito. 2015. Penerapan Model Pembelajaran ThinkPair-Share (TPS) pada Mata Diklat Membaca Gambar Teknik Untuk Meningkatkan Hasil Belajar Siswa SMK Negeri 7 Surabaya. Jurnal Pendidikan Teknik Mesin. Vol. 4, Nomor 1: 17-25.

Fad, Aisyah.2014. Kumpulan Permainan Anak Tradisional. Jakarta: Cerdas Interaktif.

Hasibuan, Ade Isma, et. al. 2018. Peningkatan Kemampuan Berpikir Kritis Siswa Melalui Model Pembelajaran Kooperatif Think Pair Share di Kelas X SMA Negeri 1 Padang Bolak. Jurnal Penelitian Tindakan Kelas dan Pengembangan Pembelajaran. Vol. 1, Nomor 3: 202-2012.
Hatma, Surya. 2017. Peningkatan Kemampuan Siswa dalam Menceritakan Pengalaman Pribadi melalui Metode Cerita Berantai pada Kelas IX 4 Semester 1 SMP Negeri 30 Pekanbaru Tahun Pelajaran 2015/2016. Jurnal Lectura Vol. 08 Nomor. 02.

Hidayah, Nurul Rosita. et. al. 2019. Penerapan Model Pembelajaran Think Pair Share dengan Permainan Puzzle untuk Meningkatkan Kemampuan Berpikir Kritis Matematika Kelas IV SD. Jurnal Teori dan Aplikasi Matematika. Vol.3, Nomor 1: 34-39.

Kusumaningsih, Alifah. 2019 Efektivitas Penerapan Permainan Tradisional Engklek Terhadap Hasil Belajar IPA Siswa Kelas IV Di SDN Lidah Wetan II/462 Surabaya. Jurnal PGSD. Vol. 7, Nomor 4: 3218 3227.

Nasution, Ismail Saleh, et .al. 2017. Pengaruh Pembelajaran Kooperatif Tipe Think Pair Share Terhadap Kemampuan Berpikir Kritis dan Hasil Belajar Matematika Siswa Kelas VI di SD Muhammadiyah 12 Medan. Jurnal Paedagoria. Vol. 8, Nomor 2: 42-52.

Prasetyo. Aji Tulus, et.al.2018. Pengaruh Model Pembelajaran Think Pair Share Berbantu Permainan Teka-Teki Berantai Terhadap Hasil Belajartematik Siswa Kelas 
V SDN Gayamsari 01

Semarang. Jurnal Pesona

Dasar. Vol.6, Nomor 1:1-

13.

Shoimin, Aris. 2017. 68 Model Pembelajaran Inovatif dalam Kurikulum 2013.

Yogyakarta: Ar-ruzz Media.

Susanto, Ahmad. 2013. Teori Belajar dan pembelajaran di Sekolah Dasar. Jakarta: Prenadamedia Groub.

Syaifullah. 2017. Menggunakan Visual Aid untuk Meningkatkan Kemampuan Berbicara (Speaking) SiswaSMA Kelas X Tahun Ajaran 2013/2014di

Kecamatan Rumbaidan

Rumbai PesisirPekanbar.

Jurnal Lectura. Vol 8, No.2.

Wardani, Dani. 2010. Permainan Tradisional yang Mendidik. Yogyakarta: Cakrawala.

Wulandari, Ari. 2012. Kisah 1001 Game/Permainan Paling Seru Di Dunia. Jakarta: PT. Grasindo. 